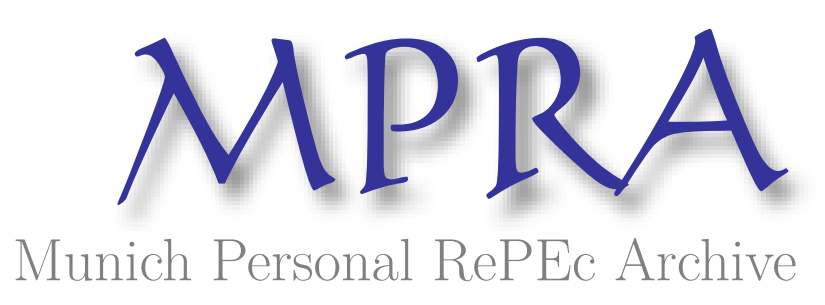

\title{
Political Economy of the Debate on Industrial Growth and Stagnation in India: A Review
}

Dutta, Sourish

Centre for Development Studies, Trivandrum

10 March 2015

Online at https://mpra.ub.uni-muenchen.de/62951/

MPRA Paper No. 62951, posted 06 Sep 2016 05:20 UTC 


\title{
Political Economy of the Debate on Industrial Growth and Stagnation in India: A Review
}

\author{
Sourish Dutta \\ M.A. Applied Economics \\ CDS, Trivandrum
}

\begin{abstract}
Slowdown of industrial growth, particularly since the late sixties, had attracted a great deal of scholarly attention in India. That ongoing scholarly discussions created a debate which was in marked contrast to the relative consensus that prevailed in the professional economic circles in the sixties. Many explanations had been offered to solve this debate. Those explanations, some mutually reinforcing, others mutually conflicting, have highlighted the following set of factors: poor agricultural performance despite the Green Revolution. relative price movements resulting in a shift in terms of trade against industry, unequal income distribution and resulting lack of demand, slowdown in import substitution, declining levels of public investment and increasing inefficiencies in the industrial structure resulting from governmental controls and policies. Now the obvious questions are: Why this incommensurability? How far do the available explanations account for the slow industrial growth? Are there other alternative explanations? On what yardsticks can we say that there has been a slowdown? Is the slowdown after 1965-66 a secular or cyclical process'? What does it mean for future policy'?[10] In this review I will try to answer these fundamental questions through analytical reasoning of different articles. ${ }^{1}$
\end{abstract}




\section{Prologue}

Growth of aggregate industrial production from 1951 to 1966 was reasonably good. From the table 1 ( Source: Structural Retrogression in the Indian Economy since the Mid-Sixties / S. L. Shetty[8]) we can see that the general index of industrial production increased at the annual compound rates of $5.7 \%, 7.2 \%$ and $9 \%$ in the three phases of 5 years interval respectively. These growth rates are similar to growth rates of output of large scale manufacturing of three consecutive five year plans. These growth rates fell short of the respective targets ( $7 \%, 10 \%$ and $11 \%)$ set by the planning commission. Nevertheless, it was a period of accelerating industrial growth.

Table 1: Annual Compound Growth Rates of IIP: Overall \& Group-wise

\begin{tabular}{|c|c|c|c|c|c|c|c|c|}
\hline & $\begin{array}{l}\text { Groups } \\
\text { (1) }\end{array}$ & $\begin{array}{l}1947 \\
\text { to } 1951(\mathrm{~d}) \\
\left(\begin{array}{l}4 \text { years }) \\
(2)\end{array}\right.\end{array}$ & $\begin{array}{l}1951 \\
\text { to } 1955(\mathrm{c}) \\
(4 \text { years }) \\
(3)\end{array}$ & $\begin{array}{l}1955 \\
\text { to } 1960(\mathrm{~b}) \\
(5 \text { years) } \\
(4)\end{array}$ & $\begin{array}{l}1960 \\
\text { to } 1965(a) \\
\text { (5 years) } \\
(5)\end{array}$ & $\begin{array}{l}1965 \\
\text { to } 1970(a) \\
(5 \text { years) } \\
(6)\end{array}$ & $\begin{array}{l}1970 \\
\text { to } 1976(a) \\
\text { (6 years) } \\
(7)\end{array}$ & $\begin{array}{l}1965 \\
\text { to } 1976(a) \\
(11 \text { years }) \\
(8)\end{array}$ \\
\hline I & $\begin{array}{l}\text { Use-based of Functional Classificution } \\
\text { (1) Basic industries } \\
\text { (2) Capital goods industrics } \\
\text { (3) Intermediate goods industrics } \\
\text { (4) Consumer goods industries } \\
\text { (a) Consumer durable goids } \\
\text { (b) Consumer non-durable } \\
\text { goods }\end{array}$ & $\begin{array}{l}- \\
- \\
- \\
-\end{array}$ & $\begin{array}{l}4.7 \\
9.8 \\
7.8 \\
4.8 \\
- \\
-\end{array}$ & $\begin{array}{r}12.0 \\
13.1 \\
6.4 \\
4.4 \\
- \\
-\end{array}$ & $\begin{array}{r}10.4 \\
19.6 \\
6.9 \\
4.9 \\
11.0 \\
\\
-\end{array}$ & $\begin{array}{r}6.2 \\
(-) 1.4 \\
2.6 \\
4.1 \\
8.5 \\
2.8\end{array}$ & $\begin{array}{l}6.8 \\
6.0 \\
3.3 \\
2.9 \\
4.3 \\
2.9\end{array}$ & $\begin{array}{l}6.5 \\
2.6 \\
3.0 \\
3.4 \\
6.2 \\
2.8\end{array}$ \\
\hline 11 & $\begin{array}{l}\text { Input-based classificution } \\
\text { (1) Agro-based industries } \\
\text { (2) Metal-based industries } \\
\text { (3) Chemicals-based industries }\end{array}$ & $\begin{array}{r}0.3 \\
4.5 \\
26.2\end{array}$ & $\begin{array}{l}4.0 \\
7.5 \\
8.5\end{array}$ & $\begin{array}{r}3.8 \\
14.1 \\
12.2\end{array}$ & $\begin{array}{r}4.0 \\
18.2 \\
9.0\end{array}$ & $\begin{array}{l}1.7 \\
0.7 \\
9.8\end{array}$ & $\begin{array}{l}1.8 \\
5.1 \\
7.3\end{array}$ & $\begin{array}{l}1.7 \\
3.1 \\
8.4\end{array}$ \\
\hline Gene & $\begin{array}{l}\text { Classification based on Sectoral } \\
\text { Indicators(d) } \\
\text { (1) Transport equipment and al- } \\
\text { lied industries } \\
\text { (2) Electricity and allied industries } \\
\text { neral Index }\end{array}$ & $\overline{4.8}$ & $\begin{array}{r}10 . \overline{4} \\
5.7\end{array}$ & $\begin{array}{r}14 . \overline{7} \\
7.2\end{array}$ & $\begin{array}{r}14.4 \\
14.4 \\
9.0\end{array}$ & $\begin{array}{r}(-) 2.2 \\
11.8 \\
3.3\end{array}$ & $\begin{array}{l}4.8 \\
6.8 \\
4.7\end{array}$ & $\begin{array}{l}1.6 \\
9.1 \\
4.1\end{array}$ \\
\hline
\end{tabular}

Sources and Notes: (a) For columns (5) to (8), see various issues of the Reserve Bank of India's Monthly Bulletines. In these, annual Compound Growth Rates represent simple averages of individual (point) annual growth rates analogous to compoind rate derived on the basis of exponential trend fitting. For the periods 1960 to 1965 and 1965 to 1970 , the CSD's Index Number series used is the one with base $1960=100$ and for the period 1970 to 1976 the series with base $1970=100$.

(b) For column (4), see RBI : "Report on Currency and Finarce: 1966-67", Statement 8 (pp s 16-17). For the period 1955 to 1960 , the CSO's index number series with $1956=100$ has been used. The compound growth rate is based on the conventional formula using initial and terminal figures.

(c) For column (3), the group indices have been specially worked out by us, using the RBI classification and the CSO's index number series with base 1956=100. See CSO: Monthly statistics of the Production of selected Industries of India for Jiuly and August 1966. The compound growth rate is as in (b) above.

(d) Column (2) and II and III Classification Columns (3) and (4), See K N Raj : "Growth and Stagnation in Industrial Development" Economic and Political Weekly, Annua! Number, February 1976, p 225-i.

Growth of industrial sub-sectors was characteristically uneven. Agro-based and non-durable consumer goods industries experienced low and relatively stable growth of $4 \%$ to $3 \%$ per phases respectively. Industries producing durable consumer goods, metal based products, machinery, electricity and allied things expanded at substantially higher but unstable rates. Consistent with the planned strategy of industrialisation, the pattern of industrial growth was distinctly oriented towards the capital goods and heavy industries. The highest growth was experienced by capital goods followed by chemicals, metal-based, consumer goods and agro-based industries. Besides this, the share of capital goods and basic goods in aggregate industrial production increased much. It seemed that the void in the capital goods sector left by the British had been filled. 
Significantly enough, the industrial growth on the whole (except chemical-based industries) was losing momentum in the 1960s, with better performing industrial sectors showing signs of faltering. From the above table it can be noted that the faster growing industrial sub-sectors were clearly slowing down at the end of third phase. By fourth phase (1965-70) the growth of all kinds of industries had slowed down. This phase of deceleration in industrial growth in fact continued for almost a decade. The period 1965-75 is therefore considered to be one of industrial stagnation.

Actually, the great deal of controversy arose over the causes of this slowdown of industrial growth as an improvement in the balance of payments situation and an increase in the rate of savings were identified as factors that would accelerate the growth rate. This, however, did not happen, even as the balance of payments situation improved and the rate of savings went up markedly from 9 per cent of the GDP in the early fifties to 22 per cent in the early eighties.[10] Bagchi (1975), Raj (1976), Shetty(1978), Nayyer (1978), Chakravarty (1979) and Lance Taylor (1988) attribute the industrial stagnation to the lack of expansion of home market, while Desai (1981), Rangrajan (1982), and Ahluwalia (1985) attribute it to supply factors, mainly labour inefficiency and the regulatory industrial policy.[9]

\section{Key Points of Discussion}

Before explanations for a slowdown could be examined or given, there was the initial question of what reference points should be chosen in relation to which the slowness of industrial growth could be demonstrated. Of the three yardsticks mentioned - slow in comparison with (a) some other period, (b) some other countries, and (c) potential - there was some disagreement on the first two (and considerable agreement on the third). A derivative of this disagreement was the view that slowdown of growth was not the right question to ask. India failed, according to this view, on distribution, not on growth. ${ }^{2}[10]$

Periodisation is essentially a matter of choosing a dividing line (or a set of cut-off points) on the basis of some explicit and defensible criterion. There was some disagreement on what this dividing line should be. Most participants favoured the mid-sixties as a cut-off point. The planning process was interrupted around this time, and it never recovered its erstwhile importance again. Agriculture ran into a deep crisis that led to the initiation of a new agricultural strategy. And finally, the rates of growth for the industrial sector before and after 1965-66 have been found to be different to a statistically significant degree.[10]

If we compare India's industrial growth performance in the last two decades with that of Low Income Countries (LICs) in general, we find that there is a slowing down in LICs in general; India on this reading in fact slowed down less. If inter-country comparison within the LIC group is to be pursued, the only comparable cases are China and India. And this comparison is not simply warranted on equity grounds; even the overall economic growth rates, despite being relatively similar, called-for a comparative analysis. For it had to be kept in mind, according to one participant Francine Frankel, compared to India, China started in 1950 from a much higher base - yields 
were higher, the ratio of sown area to available land was very high - which made its potential for future growth smaller. Conversely, India's lower starting base implied a larger potential for growth. Achievement of similar growth rates, given this difference in starting points, makes China's performance much superior and India's sluggish growth worth reflecting on. India, in other words, has done badly on both growth and equity, not simply on the latter.[10]

\section{Explanations for Slow Growth}

The explanations offered for slow growth were of two types: 'proximate' explanations on which there was considerable agreement, and 'foundational' or underlying explanations on which disagreements were substantial.[10] But before these, we will discuss some latent failures regarding this industrial slowdown.

\section{A. Latent Weakness}

Up to 1965 three latent strains were operating on industrial growth:

1. Poor performance of agriculture.

2. Narrow base for home market for industrial goods.

3. Low innovation propensity of industrialists, with negligible local adaptation of imported technology by them.

The adverse effects of each of these factors were apparently important. But individually none of them was strong enough to arrest industrial growth. It was their cumulative and additive effect which restrained industrial growth throughout the period 1956-65. Their cumulative effects reached a critical level by 1965 when a series of external shocks completely negated the forward momentum of industrial growth.[9]

Performance of agriculture over the period was dismal with growth of agricultural output decelerating from first plan $(4.6 \%$ per annum) to third plan $(-1 \%)$. The deceleration in the growth of foodgrains production was even sharper owing to the severe drought of 1966. But the full impact of this drag was not felt in the early sixties (except some commercial crops affecting the growth of agro-based industries) as the deficiency was made up by the concessional imports of foodgrains (under PL 480), which accelerated from an annual average of 0.25 crore tonnes in the first plan to 0.50 crore tonnes in the third plan. This concessional imports of foodgrains, in reality, reduced the maneuverability in matters of economic policy i.e. force for devaluation, adverse incentive for investment in agriculture, especially, low priority of public investment in agrarian reforms and thereby it restricted the rural demand for industrial product, but it alone could not have generated a decade-long industrial stagnation due to the weak linkage effect. Basically, these factors narrowed down the market for manufactured consumer goods mainly to the upper segment of the population.[9] 
Indeed, the narrow market base for industrial products was under conditions of poor performance of agriculture, non-implementation of agrarian reform, unchanged income inequalities and poverty tended to create a lag of effective demand behind industrial output. The deficiency of demand was indicated by the growing underutilisation of manufacturing capacity and by the fizzling out of industrialists' intentions to invest. There is evidence to the effect that capacity utilisation of capital goods industries suffered a major setback after mid-sixties. The table 2 (Source: Growth and Stagnation in Indian Industrial Development / K. N. Raj[5]) presents the data on potential capacity utilisation indices for the use-based categories of the industrial sector.

Table 2: Potential Utilisation for Manufacturing Industries

\begin{tabular}{|c|c|c|c|c|c|}
\hline Year & $\begin{array}{l}\text { Machinery } \\
\text { and } \\
\text { Equipment } \\
\text { Manufactu- } \\
\text { ring Industries } \\
(10.51)\end{array}$ & $\begin{array}{l}\text { Basic } \\
\text { Intermediate } \\
\text { Goods } \\
\text { Industries } \\
(10.02)\end{array}$ & $\begin{array}{l}\text { Other } \\
\text { Intermediate } \\
\text { Goods } \\
\text { Industries } \\
\text { (25.42) }\end{array}$ & $\begin{array}{l}\text { Consumer } \\
\text { Goods } \\
\text { Industries } \\
\\
(36.05)\end{array}$ & $\begin{array}{l}\text { All Manu- } \\
\text { facturing } \\
\text { Industries } \\
\\
(100.0)\end{array}$ \\
\hline $\begin{array}{l}1960 \\
1961 \\
1962 \\
1963 \\
1964 \\
1965 \\
1966 \\
1967 \\
1968 \\
1969 \\
1970 \\
1971 \\
1972 \\
1973\end{array}$ & $\begin{array}{l}76.8 \\
80.4 \\
83.7 \\
80.5 \\
84.8 \\
84.9 \\
69.4 \\
63.5 \\
62.9 \\
61.3 \\
59.2 \\
56.9 \\
57.0 \\
61.6\end{array}$ & $\begin{array}{l}84.6 \\
89.7 \\
85.9 \\
90.5 \\
88.0 \\
86.8 \\
85.2 \\
80.8 \\
83.2 \\
87.8 \\
80.5 \\
81.0 \\
86.2 \\
82.0\end{array}$ & $\begin{array}{l}89.9 \\
88.7 \\
89.8 \\
89.3 \\
88.8 \\
89.4 \\
83.3 \\
83.2 \\
84.3 \\
79.1 \\
79.5 \\
77.0 \\
81.4 \\
80.3\end{array}$ & $\begin{array}{l}90.3 \\
91.4 \\
89.7 \\
85.7 \\
87.4 \\
88.1 \\
86.6 \\
81.9 \\
81.6 \\
85.0 \\
86.2 \\
82.6 \\
83.0 \\
79.8\end{array}$ & $\begin{array}{l}87.7 \\
88.9 \\
88.5 \\
86.7 \\
87.6 \\
87.9 \\
83.2 \\
79.8 \\
80.2 \\
80.5 \\
80.0 \\
77.4 \\
79.6\end{array}$ \\
\hline
\end{tabular}

Notes: (1) The weights attached to the four major categories of manufacturing industry are given in brackets. Mining and quarrying, electricity, shipbuilding and repair, etc are not covered, and hence all the industries covered in the index numbers of industrial production do not figure under "all manufacturing industries" in this table.

(2) The potential production for any given industry during a year is defined as the peak (maximum) level of monthly production attained by that industry at the point of measurement or prior to it. As the official index numbers of industrial production are available on a monthly basis for a number of industries, the potential production of an industry for a year has been taken as the peak level reached by the monthly production index for the industry during the year under consideration. For highly seasonal industries like tea, salt and sugar, an exception has been made by considering the peak annual average production index as the potential for a particular year because otherwise the utilisation beccmcs much lower than that for other industries which do not show such pronounced seasonal pattern. In the case of these industries also the pctential is assumed to be non-decreasing.

Source: Reserve Baink of India Bulletin, April 1970, March 1972, October 1973 and September 1975. 
At the same time, corporate intensions to invest as reflected in the the number of industrial licenses peaked at 1900 in 1960, sharply declining thereafter to 1400, 1100, 974, 786, 530 and 423 over the next six years[2]; corporate investment also declined with a time-lag of five years. [6] Similarly, another important weakness that persisted in the economy was the virtual absence of suitable innovations in industry. The economics of diffusion and of innovation of techiiques is a very complex matter. But two important factors inhibiting innovations or local adaptations that spring to mind are (a) the costliness of adaptation or innovation by the individual producer, particularly where the potential markets are small and slow-growing and (b) the prevailing xenophilia among bureaucrats, politicians and even scientists in India. (The underpricing of loan capital by public financial institutions is also a factor).[1]

These latent weaknesses necessarily created the conditions for slow-down in industrial growth. But in the face of a vigorous expansion of the public sector, their impact on industrial growth remained dormant until 1965.[9]

\section{B. Proximate Causes}

Two mutually reinforcing proximate explanations were given. One associated deceleration in industrial growth with deceleration in public investment and the other pointed to the rise in capital output ratios.[10] The table 3 (Source: Industrial Growth in India / I.J. Ahluwalia) below shows the composition of net public investment. It can be noted that the effect of the slowdown in public investment was borne disproportionately by the infrastructure sectors, e.g. the railways and power. These infrastructural inputs affect the entire industrial sector, a comprehensive supply side linkage, that added to the role of public investment in creating demand for capital goods, makes public investment absolutely crucial to the functioning of the industrial sector. Any sustained cutbacks therein would inevitably hurt the entire sector. As it turned out, the cutbacks in investment in crucial sectors such as the railways were particularly severe.[3][10]

Table 3: Composition of Public Investment

\begin{tabular}{|c|c|c|c|c|c|c|c|}
\hline & & \multicolumn{3}{|c|}{$\begin{array}{l}\text { Share in Total } \\
\text { (per cent) }\end{array}$} & \multicolumn{3}{|c|}{$\begin{array}{l}\text { Growth by Sector } \\
\text { (per cent per annum) }\end{array}$} \\
\hline & & $\begin{array}{l}1960-1 \\
\text { to } \\
1965-6\end{array}$ & $\begin{array}{l}1966-7 \\
\text { to } \\
1975-6\end{array}$ & $\begin{array}{l}1976-7 \\
\text { to } \\
1980-1\end{array}$ & $\begin{array}{l}1960-1 \\
\text { to } \\
1965-6\end{array}$ & $\begin{array}{l}1965-6 \\
\text { to } \\
1975-6\end{array}$ & $\begin{array}{l}1975-6 \\
\text { to } \\
1980-1\end{array}$ \\
\hline 1. & Agriculture & 12.4 & 14.0 & 16.7 & 7.9 & 3.0 & 12.0 \\
\hline 2. & Manufacturing & 18.6 & 18.9 & 20.1 & 6.6 & 1.7 & 8.2 \\
\hline 3. & Infrastructure & 36.1 & 28.8 & 32.1 & 16.7 & 2.1 & 8.3 \\
\hline & a. Railways & (16.6) & (7.1) & $(4.6)$ & (12.5) & $(-7.7)$ & (9.1) \\
\hline & b. Electricity, gas and water & (16.4) & (18.9) & (21.6) & (23.7) & (4.2) & $(5.6)$ \\
\hline & c. Mining & (3.1) & $(2.8)$ & $(5.8)$ & (2.4) & $(15.8)$ & $(6.4)$ \\
\hline & $\begin{array}{l}\text { Public Administration } \\
\text { and defence }\end{array}$ & 23.5 & 20.1 & 15.8 & 0.6 & -0.1 & 11.6 \\
\hline 5. & Trade, hotels and restaurants & 1.0 & 5.4 & 3.3 & 69.5 & 21.3 & -30.2 \\
\hline 6. & Other & 8.4 & 12.8 & 12.0 & 10.9 & 8.1 & -5.7 \\
\hline & Total & 100.0 & 100.0 & 100.0 & 9.2 & 3.9 & 3.6 \\
\hline
\end{tabular}


Now the question is: what were the reasons for this sharp decline in the growth of public investment? Basically, it was due to two wars and two droughts in quick succession. The wars with China and pakistan sharply increased defence expenditure, which rose from 2\% of NNP before 1962 to around $4 \%$ of NNP between 1962 and 1972. Foreign aid was (temporarily) suspended during the Indo-Pak war. It caused a sudden readjustment in budgetary allocations to the detriment of public investment. The droughts of 1965 and 1966 meant a decline in foodgrains production by 1.7 crore tonnes and an import to the extent of 1 crore tonnes, raising food imports to about one-third of the total import bill. The government was therefore forced to divert resources from industrial infrastructure to agriculture. However, under these conditions the tempo of industrialisation could be sustained only if additional resources were mobilised. But the government was unable to mobilise adequate funds for its developmental and non-developmental activities through non-inflationary methods. Strains were in fact developing on both the expenditure and revenue side of the government budget.[9]

The second and supplementary proximate explanation - high and rising incremental capital output ratios -was thought to be the reason for the incommensurability. This rise, it was argued, is not simply due to a relative shift in the pattern of recent industrial involvement towards relatively capital-intensive and/or long-gestation industries like chemical fertilisers, petro-chemicals and electricity generation; rather, all industry groups show a rise in capital output ratios, but it is particularly pronounced in the public sector. In sectors where both public and private enterprises operate, the capacity utilisation ratio of public enterprises is normally lower by 15 to 20 percentage points.[10]

\section{Underlying Explanations}

The principal underlying explatnations and their policy implications, on both of which consensus could be reached, can be classified into four categories.[10]

1. That slow growth was an inevitatble result of the overall industrial policy regime which, because of comprehenisive controls and a systematic blunting of foreign and domestic competition, led to inefficiencies.misallocation of resources and creation of a high cost industrial structLire. The way out is to liberalise the economy.

- Nearly all the elements of the industrial policy regime ranging from matters like investment, capacity creation, technology choice, prices, foreign collaboration to the entire import substitution strategy - have had a 'growth chocking effect'. ${ }^{3}$

- Liberalisation, in this view, is essential if growth is to be stimulated. Liberalisation measures so far have been quite ad hoc and partial. What is required is: (i) a step-up in public investment but only in critical infrastructure sectors - indeed even power generation could be de-nationalised; (ii) a more well thought out, systematic and ultimately comprehensive liberalisation of the economy. This could be initiated step by step, i.e. in a cost-minimising way. A 'one fell swoop approach' can neither be expected nor is it 
desirable; and (iii) a revamping of Centre-state relations toward greater decentralisation - cconomic, political and administrative -so that a climate of incentives and independence of action at lower- levels is produced, a climate that would complement the forces of competition and efficiency that would result from liberalisation.

2. That (1) is a stagnationist argument. It could well be the case that inefficiencies themselves were a result of inadequate aggregate demand. Since the mid-sixties the government policies have been inadequatelv expansionary; the problem of slow growth could be solved by pumping aggregate demand in a plantned and systematic way through higher public investment and/or better income distribution. ${ }^{4}$

- Empirical results show that policy variables like government consumption and investment expenditures have played a crucial role in influencing the industrial production in India during the three decades 1960-1990. These are all demand variables. Another factor is also found to have been important, viz, the growth of the agricultural output - perhaps a mixed variable representing both demand pressures and supply of wage goods. These are in fact the variables which are supposed to play vital roles in process of industrialisation in the various dual economy models. [4]

3. That public investment has declined because resource mobilisation has been the overarching constraint. This in turn is due to the fact that the vast agriculture sector remains untaxed. With limited public resources, the state has had to finance a large part of both agricultural and industrial growth in addition to meeting the equity goals which have been becoming increasingly politically pressing. Given the inherent limitation of the Indian state to mobilise resources from agriculture, the only realistic source of finances is foreign investment. ${ }^{5}$

4. That inefficiencies have certainly existed but in and of themselves they do not explain why public investment declined and though they can be held to partly account for rising captial output ratios, the fact remains that the industrial policy regime after the mid-sixties has not been any more restrictive than in the period before. It is more important to inquire why an inefficient regime has been perpetuated, what interests it serves, and if the answer lies in the political structure, then liberalisation may not be an easy policy matter as (1) would imply; it may require institutional rearrangement ${ }^{6}$.

\section{Effects of Industrial Slow-down}

The effects of the slow-down in industrial growth were far-reaching.[9]

- Firstly, The productive capacities created in this sector up to 1965 could not be fully utilised in the second half of the sixties. As a result, the capital-output ratios rose to permanently higher levels. It should be noted a large chunk of investment, by design, was undertaken in capital-intensive industries, which obviously resulted in a reduction in the employment potential of additional capital investment. 
- Secondly, the slow-down in the growth of investment and the shrinking employment content of investment led to a virtual stagnation of employment.

- Thirdly, droughts and the emerging excess capacities in manufacturing industries triggered off an inflationary spiral that tended to become permanent feature of the economy.

Therefore, the obvious question would come in our mind is: how did the government react to this industrial crisis? Actually, the government's response to the deceleration in industrial growth was the suspension of planning. The original fourth five year plan draft (1966-71), prepared in 1966, was shelved and for the next three years planning came to mean just the formulation of annual plans, that too for a part of the public outlays. This suspension of planning as well as the much expected gradual delicencing of industries paved the way for enlarging the sphere of operation of big private Indian and foreign businesses. In February 1970 the large industrial houses as well as foreign companies were allowed to the core and heavy investment sectors. After that the policy orientation of our economy became out-centric rather than in-centric.[9]

\section{Epilogue}

Before I conclude this analysis, let us have a quick view of how generally accepted the retardation thesis has been. One of the first salvoes was fired by K N Raj in 1976 when, in an article concerned with 'Growth and Stagnation in Indian Industry', he wrote about "a sharp decline in the rate of growth of industrial output since the middle sixties". In the following year, Srinivasan and Narayana (1977) observed that "since i966 the Indian economy seems to have departed significantly from the growth trends established during the first three Plans". Vaidyanathan (1977) took up issue with Srinivasan and Narayana about the explanation for ". . the sluggish growth of output and investment during the last decade". Shetty (1978) in his ambitious study set out to explain why "in comparison with the overall economic performance during the first fifteen years of planning ... the performance of the Indian economy since the mid-sixties has been very unsatisfactory". Prabhat Patnaik in 1981 advanced "an explanatory hypothesis" for "industrial stagnation in particular and economic stagnation in general". Rangarajan in 1982 talked of "the deceleration of the industrial growth" as a "disturbing feature" calling "for serious attention". Ahluwalia in 1985 undertook a comprehensive study of "industrial stagnation in the organised sector after the mid-sixties".[7]

One is, therefore, justified in recognising a general consensus among economists on there having been a slowing down of industrial growth. However the cited article says that a careful review of the relevant data does not lend support to the hypotheses of industrial retardation and slowing down of public sector investment which have been subjects of so much discussion among Indian economists... It is not being suggested that the economists who debated industrial 'retrogression' were wrong. They were certainly right about their own time frames of comparison. This different result clearly indicate that the retardation of seventies was not a durable feature of our economy's pattern of development. ${ }^{7}[7]$ So detection of industrial slow-down is depending upon your method through which you want to do this analysis of retrogression. 


\section{Notes}

${ }^{1}$ The cited article puts together in an organised form the discussion that took place in a conference sponsored by the Social Science Research Council on the 'Political Economy of Slow Industrial Growth in India'. It was held at the Center for International Studies, MIT in October 1983. This two-day long conference brought together economists and political scientists, both from within the United States and outside, to discuss the problem of slow industrial growth in India, particularly since the mid-sixties. The above mentioned questions were the central questions before that conference in MIT.

${ }^{2}$ Position taken in the conference by the discussant, Amartya Sen.

${ }^{3}$ Position taken by Isher Judge Ahluwalia, Robert Lucas and T.N. Srinivasan

${ }^{4}$ Lance Taylor held this view

${ }^{5}$ Argument advanced by Francine Frankel

${ }^{6}$ Key argument developed by Pranab Bardhan around which the conference was structured.

${ }^{7}$ Authors took the entire series from 1961 to 1985 as a single segment. They fitted in each case to the entire data a log-quadratic growth curve (of the form $\log Y_{t}=a .+b . t+c . t^{2}$ ) and then tested for the significance of the quadratic term. In a large number of cases they have found the term to be non-significant and they have interpreted these cases to be homogeneous over the entire period with a constant growth rate. In some cases the quadratic term has been significant with negative sign. They have interpreted these cases to involve deceleration over the entire period. In some cases the quadratic term has been significant with positive sign and they have had no option but to treat those cases as involving growth with increasing rate. 


\section{References}

[1] A. K. Bagchi. "Some Characteristics of Industrial Growth in India". In: Economic and Political Weekly 10.5/7 (1975), pp. 157-164.

[2] R.K. Hazari. Industrial Planning and Licensing Policy. Final Report. Planning Commission.

[3] I.J.Ahluwalia. Industrial Growth in India: Stagnation Since the Mid-Sixties. OUP.

[4] Pradip Maiti and R. Kavita Rao. "Demand Side Factors and India's Industrial Growth". In: Economic and Political Weekly 30.33 (1995), pp. 2070-2073.

[5] K. N. Raj. "Growth and Stagnation in Indian Industrial Development". In: Economic and Political Weekly 11.5/7 (1976), pp. 223-236.

[6] C. Rangarajan. "Industrial Growth: Another Look". In: Economic and Political Weekly 17.14/16 (1982), pp. 589-604.

[7] Snigdha Chakrabarti \& Ashok Rudra. "Where Is the Industrial Retardation?" In: Economic and Political Weekly 25.39 (1990), pp. 2205-2208.

[8] S. L. Shetty. "Structural Retrogression in the Indian Economy since the Mid-Sixties". In: Economic and Political Weekly 13.6/7 (1978), pp. 185-244.

[9] Dalip S. Swamy. The Political Economy of Industrialisation: From self-reliance to globalisation. SAGE Publications.

[10] Ashutosh Varshney. "Political Economy of Slow Industrial Growth in India". In: Economic and Political Weekly 19.35 (1984), pp. 1511-1517. 